\title{
Peningkatan Keefektifan Bioherbisida Berbahan Dasar Umbi Teki dengan Surfaktan dalam Menekan Perkecambahan
}

\author{
Increasing the Effectiveness of Purple Nutsedge-Based Bioherbicides \\ by Surfactant in Supressing the Germination
}

\author{
Agung Jat Wibowo Arsa ${ }^{1}$, Muhamad Achmad Chozin' ${ }^{2 *}$, dan Adolf Pieter Lontoh ${ }^{2}$ \\ ${ }^{1}$ Program Studi Agronomi dan Hortikultura, Departemen Agronomi dan Hortikultura, Institut Pertanian Bogor \\ ${ }^{2}$ Departemen Agronomi dan Hortikultura, Fakultas Pertanian, Institut Pertanian Bogor \\ (Bogor Agricultural University), Jl. Meranti, Kampus IPB Darmaga, Bogor 16680, Indonesia
}

Diterima 21 Januari 2020/Disetujui 24 Maret 2020

\begin{abstract}
Previous studies stated that the solution of purple nut sedge tuber powder has the potential as a pre-emergence bioherbicide to control broad-leaf weeds. This study aimed to: determine an effective concentration level of tuber powder solution, find out information on the types of effective surfactants in order to be mixed in tuber powder solutions in inhibiting germination, and find out the interaction between the tuber solution and the addition of surfactants towards the germination of plant seeds. This study was conducted from February to April 2019 in a greenhouse at the Cikabayan Experimental Station, IPB University. The research used a completely randomized design (CRD) with two-factors and three replications. The first factor was the type of surfactants, consisting of A0 (with no surfactant), A1 Tween 80, A2 Triethanolamine (TEA), and A3 Nonylphenol 10 (NP10) with 2\% concentration. The second factor was the solution concentration, including K0 (control), K1 (45 $\left.g L^{-1}\right)$, K2 $\left(90 \mathrm{~g} \mathrm{~L}^{-1}\right)$, and $K 3\left(135 \mathrm{~g} \mathrm{~L}^{-1}\right)$. The results showed that the tuber powder solution significantly affected several germination parameters. In addition to suppressing the percentage of germinating seeds, the solution of tuber powder could also inhibit the growth rate and increased the percentage of abnormal sprouts. The response to the concentrations used was linear and still ineffective enough for suppressing seed germination. In this study, the types of surfactants used were unable to increase the effectiveness of the tuber powder solution as a bioherbicide. Lettuce and Asystasia gangetica broad leafy plants are more sensitive to the treatment than paddy rice.
\end{abstract}

Keywords: allelopathy, Asystasia gangetica, bioherbicide, Cyperus rotundus, sustainable agriculture

\section{ABSTRAK}

Hasil penelitian sebelumnya menyatakan bahwa larutan tepung umbi teki berpotensi sebagai bioherbisida pratumbuh untuk mengendalikan gulma berdaun lebar. Penelitian ini bertujuan mengetahui tingkat konsentrasi larutan tepung umbi teki yang efektif, mendapatkan informasi jenis surfaktan yang efektif digunakan untuk campuran larutan tepung umbi teki dalam menghambat perkecambahan, dan mengetahui interaksi antara larutan dengan penambahan surfaktan terhadap perkecambahan. Percobaan dilakukan pada Februari-April 2019 di rumah kaca Kebun Percobaan Cikabayan IPB. Penelitian ini menggunakan rancangan acak lengkap (RAL) dua faktor dengan tiga ulangan. Faktor pertama yaitu perlakuan surfaktan yang terdiri dari $A_{0}$ (tanpa surfaktan), $A_{1}$ Tween 80, A Triethanolamin (TEA), dan $A_{3}$ Nonylphenol 10 (NP10) pada konsentrasi 2\%. Faktor kedua perlakuan konsentrasi larutan yaitu $K_{0}$ (kontrol), $K_{1}\left(45 \mathrm{~g} \mathrm{~L}^{-1}\right), K_{2}\left(90 \mathrm{~g} \mathrm{~L}^{-1}\right)$, dan $\mathrm{K}_{3}\left(135 \mathrm{~g} \mathrm{~L}^{-1}\right)$. Hasil penelitian menunjukkan bahwa larutan tepung umbi teki berpengaruh nyata terhadap beberapa parameter perkecambahan. Selain menekan persentase benih yang berkecambah, larutan dapat menghambat kecepatan tumbuh dan meningkatkan persentase kecambah abnormal. Respon terhadap konsentrasi bersifat linier dan belum efektif menekan perkecambahan pada media tanah. Jenis surfaktan yang digunakan tidak nyata meningkatkan keefektifan bioherbisida. Tumbuhan berdaun lebar selada dan Asystasia gangetica lebih peka terhadap perlakuan dibandingkan dengan padi.

Kata kunci: alelopati, Asystasia gangetica, bioherbisida, Cyperus rotundus, pertanian berkelanjutan

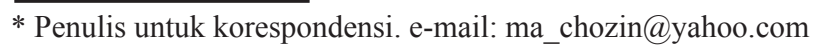




\section{PENDAHULUAN}

Penggunaan herbisida semakin meningkat sejalan dengan peningkatan luas lahan pertanian, khususnya perkebunan (Benbrook, 2016). Penggunaan herbisida secara terus-menerus akan memberikan pengaruh negatif seperti: resistensi terhadap herbisida tersebut (Rahmadhani et al., 2016) dan menurunkan kesuburan tanah (Yuantari, 2011). Hal ini karena bahan aktif yang terkandung dalam herbisida dapat mematikan biota-biota tanah seperti cacing tanah (Sari et al., 2015). Selain itu, penggunaan herbisida secara terusmenerus dapat mengganggu kesehatan (Pamungkas, 2016).

Salah satu alternatif untuk mewujudkan pertanian berkelanjutan ialah dengan menggunakan herbisida berbahan alami (bioherbisida). Allelopati menjadi senyawa penting dalam pembuatan herbisida alami (Kusuma et al., 2017). Tanaman yang mengandung allelopati antara lain: Acasia, Centaura sp. L., C. maculosa L., C. diffusa L., Imperata cylindrica L. (alang-alang), Agropyron repens L. (rumput Quack), Cyperus rotundus L. (teki) (Djazuli, 2011). Tumbuhan tersebut menyebabkan penurunan produksi pada tanaman sekitarnya (Dewi et al., 2017). Penelitian Cyperus rotundus di Institut Pertanian Bogor sudah dilakukan sejak tahun 2010. Menurut Chozin et al. (2013) pemakaian mulsa teki(C.rotundus) kering dapat menurunkan bobotkering pada gulma, dan dapat menekan pertumbuhan gulma. Penelitian ekstrak teki di laboraturium menunjukkan bahwa pada ekstrak umbi teki Cyperus rotundus mampu menghambat pertumbuhan gulma Asystasia gangetica, Mimosa pigra, dan Borreria alata (Delsi, 2012). Selanjutnya Chozin et al. (2013) menyatakan bahwa ekstrak teki Cyperus rotundus dapat menghambat pertumbuhan gulma berdaun lebar, serta berpotensi dapat digunakan sebagai herbisida pra-tumbuh (pre-emergence).

Penelitian pendahuluan tentang formulasi umbi teki sebagai bioherbisida menunjukkan bahwa formulasi yang paling efektif adalah dalam bentuk tepung. Selanjutnya Andhini dan Chozin (2017) melaporkan bahwa ekstrak dari tepung umbi teki yang diuji pada berbagai jenis tanah yaitu kuarsa, regosol, andosol, dan podsolik menunjukkan keefektifan yang berbeda. Kusuma et al. (2017) melaporkan bahwa salah satu senyawa fenol 2-furan methanol yang terkandung dalam umbi teki dapat menekan perkecambahan Asystasia gangetica. Menurut Nuryana et al. (2019) selain senyawa fenol, juga terdapat senyawa sesquiterpen yaitu $\alpha$ cyperone yang juga dapat menekan perkecambahan. Hasil penyemprotan larutan tepung umbi teki masih belum efektif ketika diaplikasikan ke media tanah dibandingkan dengan media cawan petri (Chairannisa dan Chozin, 2018). Hal ini disebabkan terjadinya pencucian pada tanah ketika terkena air.

Menurut Agustina et al. (2017) cara mengatasi hal tersebut dengan penambahan surfaktan pada teknik formulasinya yang berfungsi sebagai perekat, perata, serta pelindung dari pencucian air pada tanah. Surfaktan mampu memecahkan molekul-molekul air sehingga dapat memperluas dan meratakan area penyebaran ekstrak bioherbisida menjadi lebih optimal (Suhardjadinata et al., 2019). Meizar et al. (2017) menjelaskan surfaktan yang bersifat nonionik dan kationik pada umumnya mampu meningkatkan daya rekat dan sebar pada herbisida yang dicampurkan, sehingga perlakuan pestisida dapat lebih efektif. Hasil penelitian Nuryana et al. (2019) menyatakan bahwa penambahan bahan surfaktan pada larutan tepung umbi teki dapat membantu meningkatkan keefektifan larutan dalam menekan perkecambahan biji padi dan selada di media cawan petri. Penelitian ini bertujuan mengetahui tingkat konsentrasi larutan tepung umbi teki yang efektif, mendapatkan informasi jenis surfaktan yang efektif digunakan untuk campuran larutan tepung umbi teki dalam menghambat perkecambahan, dan mengetahui interaksi antara larutan dengan penambahan surfaktan terhadap perkecambahan.

\section{BAHAN DAN METODE}

Penelitian ini dilaksanakan di rumah kaca Kebun Percobaan Cikabayan IPB, Dramaga dan Laboratorium Pasca Panen, Fakultas Pertanian, IPB. Penelitian ini dilaksanakan pada bulan Februari-April 2019. Bahan dan alat yang digunakan adalah benih gulma Asystasia gangetica, selada (Kriebo) dan padi (Inpari 32), umbi teki Cyperus rotundus, aquades, tanah steril, dan surfaktan (Tween 80, Triethanolamin, dan Nonylphenol 10).

Penelitian ini menggunakan rancangan faktorial dengan 2 faktor dengan rancangan acak lengkap (RAL) dan 3 ulangan. Faktor pertama yaitu perlakuan surfaktan yang terdiri dari $\mathrm{A}_{0}$ (tanpa surfaktan), $\mathrm{A}_{1}$ (Tween 80), $\mathrm{A}_{2}$ (TEA), $\mathrm{A}_{3}$ dan (NP10) pada konsentrasi 2\%. Faktor kedua yaitu perlakuan konsentrasi larutan terdiri dari $\mathrm{K}_{0}$ (kontrol), $\mathrm{K}_{1}$ (45 $\left.\mathrm{g} \mathrm{L}^{-1}\right), \mathrm{K}_{2}\left(90 \mathrm{~g} \mathrm{~L}^{-1}\right)$, dan $\mathrm{K}_{3}\left(135 \mathrm{~g} \mathrm{~L}^{-1}\right.$. Banyaknya satuan percobaan adalah 48 satuan percobaan dengan 3 ulangan serta populasi 25 tanaman/baki. Data hasil yang diperoleh dianalisis dengan uji F pada aplikasi SAS dan uji-t pada aplikasi Minitab.

Pembuatan tepung umbi teki (Cyperus rotundus L.) dilakukan beberapa tahap. Tahap pertama melakukan pencucian teki dari kotoran-kotoran dan pemotongan akar serabutnya. Pada tahap kedua dilakukan pengovenan pada suhu $60{ }^{\circ} \mathrm{C}$ dengan lama pengovenan $3 \times 24$ jam. Tahap selanjutnya penghancuran teki dengan alat blender dan penyarigan mengikuti Andhini dan Chozin (2017).

Tepung umbi teki dilarutkan dengan aquades menggunakan konsentrasi masing-masing $\mathrm{K}_{0}$ (kontrol), $\mathrm{K}_{1}$ (45 $\left.\mathrm{g} \mathrm{L}^{-1}\right), \mathrm{K}_{2}\left(90 \mathrm{~g} \mathrm{~L}^{-1}\right)$, dan $\mathrm{K}_{3}\left(135 \mathrm{~g} \mathrm{~L}^{-1}\right.$, didiamkan selama 24 jam, dan disaring serta diperas mengikuti Delsi (2012). Kemudian larutan dimasukkan ke dalam Sprayer berukuran kecil dengan volume semprot $10 \mathrm{ml} /$ baki dan pengaplikasian surfaktan dengan cara menambahkan surfaktan sebanyak $2 \%$ pada masing-masing konsentrasi. Larutan disemprotkan ke baki yang telah ditanami biji gulma Asystasia gangetica, selada (Kriebo) dan padi (Inpari 32). Biji tanaman (Asystasia gangetica, selada, dan padi) ditanam sebanyak 25 biji dengan jarak tanam $4 \mathrm{~cm}$ x $3 \mathrm{~cm}$ di dalam wadah 
baki berukuran $24.5 \mathrm{~cm}$ x $19.5 \mathrm{~cm}$ x $4.5 \mathrm{~cm}$. Penyemprotan bioherbisida dilakukan pada saat menyemai biji, dan setiap hari dilakukan penyiraman sebanyak 2 kali sehari.

Pengamatan yang dilakukan pada penelitian ini adalah perkecambahan biji gulma. Parameter yang diamati yaitu; Proses kecambah, mengamati setiap 7 hari sekali karakteristik terjadinya perubahan pada kecambah dengan melampirkan gambar setiap perlakuannya. Jumlah kecambah tumbuh normal dan abnormal, menghitung jumlah kecambah yang tumbuh dengan normal dan abnormal. Persentase perkecambahan akhir, menghitung persentase perkeambahan akhir dengan rumus

Persentase Perkecambahan Akhir $=\frac{\sum \text { Biji yang berkecambah }}{\sum \text { Total biji yang diamati }}$

Pengukuran plumula dan radikula kecambah, Kecambah yang sudah tumbuh dilakukan pengukuran plumula dari ujung pucuk hingga pangkal akar. Rentang waktu pengambilan kecambah setiap seminggu sekali dengan mengambil 3 sampel. Kecepatan tumbuh, menghitung kecepatan tumbuh dilakukan dengan melakukan pengamatan tiap harinya dan mendapatkan persentase tumbuh, dengan menggunakan rumus $K_{c t}=\sum_{i=0}^{t} \frac{\% K N}{\text { Etmal }}$

Keterangan:

$K_{c t} \quad$ : Kecepatan tumbuh

$\% \mathrm{KN} \quad$ : Persen kecambah normal

etmal : Pengamatan pertumbuhan biji setiap 24 jam

Analisis data menggunakan uji F pada taraf 5\%. Hasil yang berpengaruh nyata diuji lebih lanjut dengan Duncan Multiple Range Test (DMRT) menggunakan aplikasi SAS dan uji- $t$ dengan aplikasi Minitab.

\section{HASIL DAN PEMBAHASAN}

\section{Kemampuan Berkecambah}

Hasil sidik ragam menunjukkan bahwa konsentrasi larutan tepung umbi teki berpengaruh nyata terhadap persentase perkecambahan akhir biji selada tetapi tidak nyata mempengaruhi perkecambahan biji Asystasia gangetica dan padi.Jenis surfaktan daninteraksikonsentrasilarutandanjenis surfaktan tidak nyata berpengaruh terhadap perkecambahan biji semua tanaman uji. Tabel 1 menunjukkan persentase perkecambahan akhir biji selada pada konsentrasi larutan $90 \mathrm{~g} \mathrm{~L}^{-1}$ dan $135 \mathrm{~g} \mathrm{~L}^{-1}$ adalah $77.3 \%$ dan $71.00 \%$, lebih rendah dan berbeda nyata dengan kontrol (89\%). Besarnya penekanan kedua perlakuan tersebut masing-masing $13.11 \%$ dan $20.22 \%$. Dalam percobaan cawan petri di laboratorium, Nuryana et al. (2019) melaporkan bahwa penggunan larutan tepung umbi teki dengan konsentrasi $20 \mathrm{~g} \mathrm{~L}^{-1}$ dapat menekan perkecambahan biji selada sebesar $61 \%$. Bahkan, percobaan di laboratorium dengan metoda yang sama Chairinnisa dan Chozin (2018) untuk biji Asystasia gangetica, pemberian larutan dapat menekan perkecambahan sebesar 95.23\%. Hasil ini memperkuat hasil, yang menyatakan bahwa perlakuan larutan tepung umbi teki pada media tanah kurang efektif dalam menekan perkecambahan dibandingkan dengan percobaan di cawan petri. Hal ini diduga karena adanya adsorpsi pada tanah sehingga keefektifan larutan tepung umbi teki berkurang (Andhini dan Chozin, 2017; Chairinnisa dan Chozin, 2018).

Dalam Tabel 1 tersebut dapat dilihat bahwa semakin tinggi konsentrasi larutan makin rendah tingkat perkecamahan biji selada. Hal ini berarti bahwa keefektifan larutan pada media tanah masih dapat ditingkatkan dengan meningkatkan konsentrasi larutan tepung umbi teki.

Tabel 1. Rata-rata persentase perkecambahan Asystasia gangetica, selada, serta padi selama 14 hari setelah semai pada perlakuan konsentrasi larutan tepung umbi teki dan perlakuan jenis surfaktan

\begin{tabular}{|c|c|c|c|c|c|c|}
\hline \multirow{3}{*}{ Perlakuan } & \multicolumn{6}{|c|}{ Perkecambahan (\%) } \\
\hline & \multicolumn{2}{|c|}{ Asystasia gangetica } & \multicolumn{2}{|c|}{ Selada } & \multicolumn{2}{|c|}{ Padi } \\
\hline & PA & PK & PA & PK & PA & $\mathrm{PK}$ \\
\hline \multicolumn{7}{|c|}{ Konsentrasi g L-1 } \\
\hline 0 & 65.33 & 0.00 & $89.00 \mathrm{a}$ & 0.00 & 93.66 & 0.00 \\
\hline 45 & 47.33 & 27.55 & $80.00 \mathrm{ab}$ & 10.11 & 91.66 & 2.13 \\
\hline 90 & 59.66 & 8.67 & $77.33 b$ & 13.11 & 90.66 & 3.20 \\
\hline 135 & 47.00 & 28.05 & $71.00 \mathrm{~b}$ & 20.22 & 89.00 & 4.97 \\
\hline \multicolumn{7}{|c|}{ Jenis surfaktan } \\
\hline Kontrol & 63.66 & 0.00 & 74.66 & 0.00 & 91.33 & 0.00 \\
\hline Tween 80 & 51.00 & 19.88 & 77.00 & -3.13 & 89.33 & 2.18 \\
\hline TEA & 54.33 & 14.65 & 84.00 & -12.51 & 91.00 & 0.36 \\
\hline NP 10 & 50.33 & 20.93 & 81.66 & -9.37 & 93.33 & -2.18 \\
\hline
\end{tabular}

Keterangan: Berdasarkan uji DMRT (Duncan multiple range test) taraf 5\% angka yang disertai dengan huruf yang berbeda menunjukkan berbeda nyata pada semua isi tabel. $\mathrm{PA}=$ Perkecambahan akhir; $\mathrm{PK}=$ Penekanan kecambah 


\section{Kecambah Abnormal}

Kecambah abnormal adalah kecambah yang rusak, akar premier yang pendek atau bentuknya cacat, bentuk plumulanya yang berputar atau bentuknya tidak sempurna, serta perkembangannya yang lemah dan tidak seimbang (Prabhandaru dan Saputro, 2017). Hal tersebut terjadi karena adanya gangguan pada jaringan-jaringan tumbuh ketika proses perkecambahan, sehingga kecambah terlihat berbeda dari yang normal. Berdasarkan hasil sidik ragam, konsentrasi larutan tepung umbi teki berpengaruh nyata terhadap persentase kecambah abnormal semua jenis tanaman uji.

Perlakuan jenis surfaktan berpengaruh nyata terhadap kecambah abnormal padi, tetapi tidak nyata untuk tanaman uji lainnya. Interaksi antara perlakuan konsentrasi dan surfaktan tidak berpengaruh nyata terhadap persentase kecambah abnormal Asystasia gangetica, selada dan padi. Rata-rata persentase kecambah yang tidak normal gulma Asystasia gangetica pada konsentrasi $45 \mathrm{~g} \mathrm{~L}^{-1}, 90 \mathrm{~g} \mathrm{~L}^{-1}$ dan $135 \mathrm{~g} \mathrm{~L}^{-1}$ berkisar antara 18.24-44.89\%, lebih tinggi dan berbeda nyata dibandingkan dengan kontrol (8.97\%). Hasil Tabel 2 pada padi dan selada, perlakuan larutan tepung umbi teki secara nyata meningkatkan persentase kecambah abnormal.

Informasi ini mengindikasikan bahwa perlakuan tepung umbi teki selain mampu menekan perkecambahan, juga dapat mempengaruhi proses setelah perkecambahan dan menyebabkan kecambah yang abnormal. Besar dugaan bahwa tumbuhan yang tumbuh dari kecambah yang abnormal akan mati atau paling tidak menjadi tumbuhan yang tumbuh tidak normal. Fenomena ini memperkuat dugaan bahwa bioherbisida yang berasal dari tepung umbi teki berpengaruh pre-emergence dan early post-emergence (Adhini dan Chozin, 2016).

\section{Kecepatan Tumbuh}

Kecepatan tumbuh merupakan parameter penting dalam perkecambahan. Semakin tinggi kecepatan tumbuh suatu benih maka makin vigor kecambahnya. Hasil sidik ragam menunjukkan tingkat konsentrasi larutan tepung umbi teki berpengaruh nyata terhadap kecepatan tumbuh Asystasia gangetica dan selada, tetapi tidak nyata terhadap kecepatan tumbuh padi. Perlakuan surfaktan dan interaksi antara konsentrasi dan surfaktan juga tidak berpengaruh terhadap kecepatan tumbuh semua tanaman uji. Kecepatan tumbuh perkecambahan tanaman Asystasia gangetica pada perlakuan bioherbisida teki dengan konsentrasi $45 \mathrm{~g} \mathrm{~L}^{-1}, 90$ $\mathrm{g} \mathrm{L}^{-1}, 135 \mathrm{~g} \mathrm{~L}^{-1}$ secara berurutan $12.62 \%$ etmal $^{-1}, 13.43 \%$ etmal $^{-1}, 10.98 \%$ etmal $^{-1}$, lebih rendah dan berbeda nyata dibandingkan kontrol (18.21\% etmal $\left.^{-1}\right)$.

Hasil parameter kecepatan tumbuh perkecambahan selada pada perlakuan konsentrasi $45 \mathrm{~g} \mathrm{~L}^{-1}, 90 \mathrm{~g} \mathrm{~L}^{-1}, 135 \mathrm{~g} \mathrm{~L}^{-1}$ secara berurutan $20.16 \%$ etmal $^{-1}, 18.04 \%$ etmal $^{-1}, 14.26 \%$ etmal $^{-1}$, lebih rendah dan berbeda nyata dibandingkan kontrol (24.39\% etmal $\left.{ }^{-1}\right)$ (Tabel 2). Hal ini memperkuat dugaan bahwa tumbuhan berdaun lebar lebih peka terhadap perlakuan bioherbisida teki dibandingkan dengan rumput atau Graminae (Chozin et al., 2013; Chairinnisa dan Chozin, 2018; Nuryana et al., 2019).

\section{Panjang Plumula dan Radikula}

Konsentasi larutan tepung umbi teki, jenis surfaktan serta interaksinya tidak berpengaruh nyata terhadap panjang plumula dan radikula Asystasia gangeica dan selada. Pada tanaman padi, konsentrasi larutan dan jenis surfaktan tidak berpengaruh nyata terhadap panjang plumula dan radikula padi, tetapi interaksinya berpengaruh nyata. Pada Tabel 3 dapat dilihat bahwa kombinasi surfaktan Tween 80 dengan

Tabel 2. Rata-rata kecambah abnormal dan kecepatan tumbuh Asystasia gangetica, selada, dan padi selama 14 hari setelah semai pada perlakuan konsentrasi larutan tepung umbi teki dan perlakuan jenis surfaktan

\begin{tabular}{|c|c|c|c|c|c|c|}
\hline \multirow{2}{*}{ Perlakuan } & \multicolumn{3}{|c|}{ Kecambah abnormal (\%) } & \multicolumn{3}{|c|}{ Kecepatan tumbuh $\left(\%\right.$ etmal $\left.^{-1}\right)$} \\
\hline & A. gangetica & Selada & Padi & A. gangetica & Selada & Padi \\
\hline \multicolumn{7}{|c|}{ Konsentrasi $\left(\mathrm{g} \mathrm{L}^{-1}\right)$} \\
\hline 0 & $8.97 \mathrm{c}$ & $6.25 \mathrm{a}$ & $2.51 \mathrm{~b}$ & $18.21 \mathrm{a}$ & $24.39 \mathrm{a}$ & 40.34 \\
\hline 45 & $26.00 \mathrm{~b}$ & $13.67 \mathrm{ab}$ & $7.28 \mathrm{a}$ & $12.62 b$ & $20.16 b$ & 39.67 \\
\hline 90 & $18.24 \mathrm{bc}$ & $17.64 b$ & $6.89 \mathrm{a}$ & $13.43 b$ & $18.04 \mathrm{~b}$ & 38.12 \\
\hline 135 & $44.89 \mathrm{a}$ & $15.74 b$ & $7.09 \mathrm{a}$ & $10.98 b$ & $14.26 \mathrm{c}$ & 37.17 \\
\hline \multicolumn{7}{|c|}{ Jenis surfaktan } \\
\hline Kontrol & 22.15 & 15.28 & $4.44 b$ & 16.41 & 18.32 & 37.68 \\
\hline Tween 80 & 23.95 & 14.65 & $6.21 \mathrm{ab}$ & 12.76 & 18.27 & 39.04 \\
\hline TEA & 26.57 & 9.96 & $4.47 b$ & 13.26 & 20.76 & 38.63 \\
\hline NP 10 & 25.63 & 13.40 & $8.63 a$ & 12.82 & 19.50 & 39.94 \\
\hline
\end{tabular}

Keterangan: Berdasarkan uji DMRT (Duncan multiple range test) taraf 5\% angka yang disertai dengan huruf yang berbeda menunjukkan berbeda nyata 
konsentrasi larutan tepung umbi teki $90 \mathrm{~g} \mathrm{~L}^{-1}$ secara nyata dapat menghambat pertumbuhan plumula padi. Pada perlakuan tersebut panjang plumula adalah $11.40 \mathrm{~cm}$, lebih rendah dan berbeda nyata dibandingkan dengan kontrol (19.49 cm) dan kombinasi perlakuan lainnya, kecuali NP10 $90 \mathrm{~g} \mathrm{~L}^{-1}(15.92 \mathrm{~cm})$ dan NP $10135 \mathrm{~g} \mathrm{~L}^{-1}(15.91 \mathrm{~cm})$.

Perlakuan larutan tepung umbi teki $90 \mathrm{~g} \mathrm{~L}^{-1}$ yang ditambah Tween 80 juga secara nyata menekan pertumbuhan radikula kecambah padi. Pada perlakuan tersebut, panjang radikula padi adalah $3.18 \mathrm{~cm}$, paling rendah dan berbeda nyata dibandingkan kontrol $(7.57 \mathrm{~cm})$ dan kombinasi perlakuan lainnya yang mempunyai panjang berkisar antara 6.22-9.35 cm. Informasi ini memberikan indikasi bahwa surfaktan Tween 80 lebih baik dibandingkan dengan kedua jenis surfaktan lainnya (TEA dan NP 10).

\section{Perbandingan Respon Ketiga Tanaman terhadap Larutan Tepung Umbi Teki dan Surfaktan}

Secara umum diketahui bahwa alelopati bersifat spesifik, berpengaruh terhadap suatu jenis tetapi tidak terhadap jenis lainnya. Hasil penelitian menunjukkan tiga tanaman uji yang digunakan memberikan respon yang berbeda terhadap perlakuan larutan tepung umbi teki dan surfaktan. Tabel 4 menunjukkan persentase benih padi yang berkecambah dari seluruh perlakuan berbeda nyata dengan benih Asystasia gangetica sebesar 38.67\%. Demikian juga terdapat perbedaan nyata antra padi-selada serta seladaAsystasia gangetica. Rata-rata persentase benih kecambah padi lebih besar dibandingkan dengan kedua tanaman lainnya (Tabel 4).

Perbedaan yang nyata dalam persentase kecambah abnormal juga ditunjukkan antara selada dengan Asystasia ganetica (Tabel 4). Pebandingan ini memberikan petunjuk bahwa tiga jenis tanaman uji Asystasia gangetica, selada dan padi memberikan respon yang berbeda terhadap perlakuan larutan tepung umbi teki sebagai bioherbisida. Demikian juga perbedaan yang nyata terlihat antara selada dan Asystasia gangetica (Tabel 4).

Perlakuan larutan tepung umbi teki berpengaruh terhadap persentase kecambah abnormal (Tabel 2). Ratarata persentase kecambah abnormal padi lebih sedikit dibandingkan dengan kedua tanaman lainnya (Tabel 4). Penyemprotan larutan tepung umbi teki secara nyata menghambat kecepatan tumbuh (Tabel 2). Hasil uji$t$ menunjukkan bahwa kecepatan tumbuh kecambah padi berbeda nyata dengan selada $\left(20.12 \%\right.$ etmal $\left.^{-1}\right)$ dan Asystasia gangetica $\left(25.77 \%\right.$ etmal $\left.^{-1}\right)$. Rata-rata persentase kecambah padi yang abnormal berbeda nyata dengan selada (7.68\%) dan Asystasia gangetica (19.56\%). Rata-rata persentase kecepatan tumbuh padi lebih besar dibandingkan dengan kedua tanaman lainnya (Tabel 4). Keterangan ini lebih memperkuat hasil-hasil penelitian sebelumnya yang menyatakan bahwa alelopati teki lebih efektif menekan gulma berdaun lebar dibandingkan denga gulma golongan rumput (Chozin et al, 2013; Chairinnisa dan Chozin, 2018; Nuryana et al., 2019).

Tabel 3. Interaksi larutan tepung umbi teki dengan surfaktan terhadap panjang plumula dan radikula tanaman padi selama 14 hari setelah semai pada perlakuan konsentrasi larutan tepung umbi teki dan perlakuan jenis surfaktan

\begin{tabular}{|c|c|c|c|c|}
\hline \multirow{2}{*}{ Perlakuan } & \multicolumn{4}{|c|}{ Panjang plumula padi $(\mathrm{cm})$} \\
\hline & $0 \mathrm{~g} \mathrm{~L}^{-1}$ & $45 \mathrm{~g} \mathrm{~L}^{-1}$ & $90 \mathrm{~g} \mathrm{~L}^{-1}$ & $135 \mathrm{~g} \mathrm{~L}^{-1}$ \\
\hline Kontrol & $19.49 \mathrm{a}$ & $19.44 a$ & $19.51 \mathrm{a}$ & $19.21 \mathrm{a}$ \\
\hline Tween 80 & $20.78 \mathrm{a}$ & $19.84 \mathrm{a}$ & $11.40 \mathrm{~b}$ & $19.17 \mathrm{a}$ \\
\hline TEA & $17.26 \mathrm{a}$ & $17.74 \mathrm{a}$ & $16.62 \mathrm{a}$ & $16.88 \mathrm{a}$ \\
\hline NP 10 & $19.79 a$ & $15.92 \mathrm{ab}$ & $17.90 \mathrm{a}$ & $15.91 \mathrm{ab}$ \\
\hline \multirow{2}{*}{ Perlakuan } & \multicolumn{4}{|c|}{ Panjang radikula padi $(\mathrm{cm})$} \\
\hline & $0 \mathrm{~g} \mathrm{~L}^{-1}$ & $45 \mathrm{~g} \mathrm{~L}^{-1}$ & $90 \mathrm{~g} \mathrm{~L}^{-1}$ & $135 \mathrm{~g} \mathrm{~L}^{-1}$ \\
\hline Kontrol & $7.57 \mathrm{abc}$ & $7.58 \mathrm{abc}$ & $8.23 \mathrm{abc}$ & $7.06 \mathrm{bc}$ \\
\hline Tween 80 & $8.48 \mathrm{abc}$ & $7.14 b c$ & $3.18 \mathrm{~d}$ & $9.35 \mathrm{ab}$ \\
\hline TEA & $7.00 \mathrm{bc}$ & $7.45 \mathrm{abc}$ & $7.01 b c$ & $6.22 \mathrm{c}$ \\
\hline NP 10 & 7.53abc & $6.58 \mathrm{c}$ & $9.83 \mathrm{a}$ & $7.16 b c$ \\
\hline
\end{tabular}

Keterangan: Berdasarkan uji DMRT taraf 5\% angka yang disertai dengan huruf yang berbeda menunjukkan berbeda nyata 
Tabel 4. Perbedaan respon tanaman Asystasia gangetica, selada, dan padi terhadap perlakuan larutan tepung umbi teki dan surfaktan 14 hari setelah semai

\begin{tabular}{|c|c|c|}
\hline Perbandingan tanaman uji & Perbedaan $(\%)$ & T-test \\
\hline \multicolumn{3}{|l|}{ Parameter persentase benih berkecambah (\%) } \\
\hline Padi (91.11\%) - Selada (78.70\%) & 12.44 & * \\
\hline Padi (91.11\%) - Asystasia gangetica (52.40\%) & 38.67 & * \\
\hline Selada $(78.70 \%)$ - Asystasia gangetica $(52.40 \%)$ & 26.22 & * \\
\hline \multicolumn{3}{|l|}{ Parameter persentase kecambah abnormal (\%) } \\
\hline Padi (6.34\%) - Selada (14.02\%) & 7.68 & * \\
\hline Padi (6.34\%) - Asystasia gangetica (25.90\%) & 19.56 & * \\
\hline Selada $(14.02 \%)$ - Asystasia gangetica $(25.90 \%)$ & 11.88 & * \\
\hline \multicolumn{3}{|l|}{ Parameter kecepatan tumbuh $\left(\%\right.$ etmal $\left.^{-1}\right)$} \\
\hline Padi $\left(38.86 \%\right.$ etmal $\left.^{-1}\right)$ - Selada $\left(18.74 \%\right.$ etmal $\left.^{-1}\right)$ & 20.12 & * \\
\hline Padi $\left(38.86 \%\right.$ etmal $\left.^{-1}\right)$ - Asystasia gangetica $\left(13.09 \%\right.$ etmal $\left.^{-1}\right)$ & 25.77 & * \\
\hline Selada $\left(18.74 \%\right.$ etmal $\left.^{-1}\right)-$ Asystasia gangetica $\left(13.09 \%\right.$ etmal $\left.^{-1}\right)$ & 5.65 & * \\
\hline
\end{tabular}

Keterangan: * = berpengaruh nyata pada taraf $5 \%$ uji-t independent

\section{KESIMPULAN}

Larutan tepung umbi teki berpengaruh nyata terhadap beberapa parameter perkecambahan. Selain menekan persentase benih yang berkecambah, larutan tepung umbi teki dapat menghambat kecepatan tumbuh sebesar 40\% (Asystasia gangetica) dan 41\% (Selada), serta meningkatkan persentase kecambah abnormal sebesar 36\% (Asystasia gangetica), 11\% (Selada), dan 5\% (Padi). Larutan tepung umbi teki untuk diimplementasikan di media tanah, konsentrasi yang digunakan masih linier, belum efektif menekan perkecambahan. Pada penelitian ini jenis surfaktan yang digunakan tidak dapat meningkatkan keefektifan larutan tepung umbi teki sebagai bioherbisida. Tumbuhan berdaun lebar selada dan Asystasia gangetica lebih peka terhadap perlakuan tepung umbi teki dibandingkan dengan padi.

\section{UCAPAN TERIMA KASIH}

Terima kasih penulis ucapkan kepada Kementerian Riset Teknologi dan Pendidikan Tinggi melalui skema Penelitian Terapan Unggulan Perguruan Tinggi (PTUPT) tahun 2019 atas nama Prof. Dr. Ir. M.A. Chozin, M. Agr., yang telah mendukung pendanaan penelitian ini.

\section{DAFTAR PUSTAKA}

Agustina, E.P., H. Fauzana, A. Sutikno. 2017. Pengaruh penambahan surfaktan dalam ekstrak daun sirih hutan (Piper aduncum L.) untuk mengendalikan ulat grayak (Spodoptera litura F.) pada tanaman kedelai (Glycine $\max$ (L.) Merril). J. Online Mahasiswa UNRI. 4:1-11.
Andhini, M., M.A. Chozin. 2017. Keefektifan allelopati teki (Cyperus rotundus L.) terhadap penekanan perkecambahan biji Asystasia gangetica (L.) T. Anderson. pada berbagai jenis tanah. Bul. Agrohorti. 4:180-186.

Benbrook, C.M. 2016. Trends in glyphosate herbicide use in the United States and globally. Environ. Sci. Eur. 28:1-15.

Chairannisa, D., M.A. Chozin. 2018. Keefektifan konsentrasi dan jenis pelarut tepung umbi teki (Cyperus rotundus L.) sebagai bioherbisida pratumbuh untuk pengendalian gulma Asystasia gangetica (L.) T. Anderson. Bul. Agrohort. 6:163-170.

Chozin, M.A., Y. Delsi, R. Saputra, Syarifi, S.A. Arifin, S. Zaman S. 2013. Some studies on allelopatic potential of Cyperus rotundus L. Dalam B.H. Bakar, D. Kurniadie, S. Tjitrosoedirdjo (Eds.). The Role of Weed Science in Supporting Food Security by 2020. Proceedings of 24th Asian-Pasific Weed Science Society Conference. Bandung 22-25 Oktober 2013.

Delsi, Y. 2012. Studi potensi alelopati teki (Cyperus rotundus L.) sebagai bioherbisida untuk pengendalian gulma berdaun lebar. Tesis. Sekolah Pascasarjana. Institut Pertanian Bogor. Bogor.

Dewi, S.A., M.A. Chozin, D. Guntoro. 2017. Identifikasi senyawa fenol beberapa aksesi teki (Cyperus rotundus L.) serta pengaruhnya terhadap perkecambahan biji Borreria alata (Aubl.) DC. J. Agron. Indonesia 45:93-99. 
Djazuli, M. 2011. Alelopati pada beberapa tanaman perkebunan dan teknik pengendalian serta prospek pemanfaatannya. J. Perspektif 10:44-50.

Kusuma, A.V.C., M.A. Chozin, D. Guntoro. 2017. Senyawa fenol dari tajuk dan umbi teki (Cyperus rotundus L.) pada berbagai umur pertumbuhan serta pengaruhnya terhadap perkecambahan gulma berdaun lebar. J. Agron. Indonesia 45:100-107.

Meizar, D.V., A. Suryani, E. Hambali. 2017. Sintesis surfaktan dietanolamida (DEA) dari metil ester olein sawit menggunakan reaktor 25 liter. J. Teknologi Industri Pertanian 27:328-335.

Nuryana, F.I., M.A. Chozin, D. Guntoro. 2019. Hight performance liquid chromatography analysis for $\alpha$ cyperone and nootkatone from the tuber of nutsedge (Cyperus rotundus L.) in the tropics. Rasayan J. Chem. 12:360-365.

Pamungkas, O.S. 2016. Bahaya paparan pestisida terhadap kesehatan manusia. J. Bioedukasi 14:27-31.

Prabhandaru, I., T.B. Saputro. 2017. Respon perkecambahan benih padi (Oryza sativa L.) varietas lokal sigadis hasil iradiasi sinar gamma. J. Sains dan Seni ITS 6: E48-E52.

Rahmadhani, A., E. Purba, D.S. Hanafiah. 2016. Respons lima populasi Eleusine indica L. Gaertn resistenherbisida terhadap glifosat dan parakuat. J. Online Agroekoteknologi 4:2245-2254.

Sari, Y.K., A. Niswati, M.A.S. Arif, S. Yusnaini. 2015. Pengaruh jenis olah tanah dan aplikasi herbisida terhadap populasi dan biomassa cacing tanah pada pertanaman ubi kayu (Manihot utilissima). J. Agrotek Tropika 3:422-426.

Suhardjadinata, R. Iskandar, D.N.S. Ningtiyas. 2019. Efikasi ekstrak babadotan (Ageratum conyzoides L.) yang ditambah surfaktan terhadap kutu daun persik (Myzus persicae Sulz.). J. Media Pertanian 4:40-47.

Yuantari, C.M.G. 2011. Dampak pestisida organoklorin terhadap kesehatan manusia dan lingkungan serta penanggulangannya. hal. 187-199. Prosiding Seminar Nasional. Peran Kesehatan Masyarakat dalam Pencapaian MDG's di Indonesia. Semarang 12 April 2011. 